\title{
Environmental Aspects of use of Impregnating Compositions for Protection the Asphalt Concrete Road
}

\author{
YULIA A. UBASKINA, VICTORIA S. RYABENKO, ELENA A. CHIGORINA, \\ ANATOLY L. RAZINOV and VITALY V. BOKOV
}

Federal State Unitary Enterprise «State Scientific Research Institute of Chemical Reagents and High

Purity Chemical Substances» (FSUE «IREA»), Bogorodsky val, 3, Moscow, Russia, 107076.

${ }^{\star}$ Corresponding author E-mail: baseou@yandex.ru

http://dx.doi.org/10.13005/ojc/320619

(Received: October 26, 2016; Accepted: December 03, 2016)

\begin{abstract}
The paper describes the effect of climatic factors on the wear of the roadway. Also presents the calculation of emissions of harmful exhaust components in the atmosphere. The application of the impregnating composition to increase the life of maintenance-free operation of the roadway while reducing impact of road construction and materials to the environment.
\end{abstract}

Keywords: Weather and climatic factors, Ecology, Impregnating composition, Modified binder, Asphalt, Environment.

\section{INTRODUCTION}

Now growth and development of transport infrastructure is followed by emergence not only obvious benefits, such as increase in the gross internal income of the country, efficiency of work of all services, timely delivery of health care, providing with food products, etc., but also the negative moments. Primarily, this is due to the construction and the maintenance of the roadway. As a rule, even the asphalt concrete road, which was made in accordance with the standards, is exposed to the destructive influence of climatic and anthropogenic factors. The solar radiation, air temperature and air humidity, rainfall can be attributed to the weather and climatic factors. Under the influence of these conditions in a covering there is stretching from not free compression when cooling, deformation at water saturation a covering upon frequent transition through $0^{\circ} \mathrm{C}$ (i.e. at asphalt concrete freezing-thawing cycles which are observed not only in autumn and spring, but also during the winter period of year, at the observed global warming of climate) ${ }^{1}$.

The destruction of the roadway is the reason of a soil pollution of respective territories, air, superficial water, groundwater and the waters, which are adjacented to the roads. 
The covering defect, which is not eliminated in time can be not only a reason of the further destruction, but can be a reason of the road traffic incident.

Reducing of the influence of destructive factors on the asphalt concrete and prevention of destructive processes, is possible by protection (impregnation) , $3^{3}$ the upper layer of the road (wear layer). The integrity of this layer determines the preservation of the entire roadway in many cases. Protection of the upper layer of the road can be performed in various ways, however the most effective method - impregnation of the upper layer of a roadbed by the specially formulated protective impregnating composition forming the film interfering impact of negative factors of natural and technogenic nature and receipt of pollutants to the environment on a surface.

The aim of this work was the consideration of environmental aspects of the impregnating compositions use for protection the asphalt concrete road from the negative impact of natural and technogenic factors.

\section{MATERIALS AND METHODS}

In this work they used construction bitumen viscous of mark BND 60/90 "SlavneftYaroslavnefteorgsyntez" (YaNOS), polymeric petroleum resin (PR) «Sibplast», hydrocarbon oil solvent with a boiling point of $140-170^{\circ} \mathrm{C}$.

The general procedure for the preparation of modified viscous bitumen: softened bitumen was placed in a steel container, equipped with a mechanical stirrer, thermometer and hot plate. Bitumen was heated with stirring to $160^{\circ} \mathrm{C}$ was introduced PR (15 wt.\%), The temperature was raised to $180^{\circ} \mathrm{C}$ and the reaction mixture was kept at this temperature for 60 minutes and then cooled to room temperature.

The modified asphalt binding agent combined with the hydrocarbon oil solvent for the getting of the impregnating composition sample. The combination of binding agent and solvent were performed in a steel container, equipped with a mechanical stirrer, at a temperature of $100^{\circ} \mathrm{C}$. For this softened binder was placed in a container at a temperature of $100^{\circ} \mathrm{C}$ then they added a hydrocarbon solvent. Stirring was carried out for 15-20 min. until the dissolution of the binder in the solvent completes.

After that, the impregnating composition was processed to the test platform.

The wear of the surface was examined by using a laboratory abrasive disc LKI-2. Water saturation of asphalt concrete samples (cores) was determined by the method of capillary water saturation which is described in GOST 12801. The coefficient of clutch of a wheel of the car with asphalt concrete after processing by impregnating composition was determined by the portable device PPK-F according to GOST 30413.

The calculation of exhaust emissions reducing as a result of reducing the amount of damage on the treated with impregnating composition road, leading to the emission of the largest amount of pollution by the car due to braking and (or) stop the car before the road damage (holes, potholes, ruts) and its following movement in the "acceleration mode" was calculated by the procedure given in GOST R 56162.

\section{RESULTS AND DISCUSSIONS}

For protection of road asphalt concrete against negative impact of natural and technogenic factors treat environmental aspects of use of impregnating composition:

1. The protection of the roadway upper layer from increased wear due to the impact of negative factors, such as precipitation and freezing thawing cycles;

2. The reducing the exhaust emissions as a result of reducing the amount of damage on the road treated by impregnating composition, leading to the emission of the largest amount of the pollutions by cars due to braking and (or) stop the car before the road damage (holes, potholes, ruts) and the following "acceleration mode";

3. The increase of maintenance-free service life 
while reducing the impact of road construction works and materials on the environment, resource conservation.

Wear resistance of the asphalt concrete can deteriorate with the longstanding exposure of moisture, as well as with the short-term exposure, but often repeated moisturization, due to the entering of moisture and bitumen film (in case of bad adhesion) or stratification of stone material (with a plate or the fibrous structure of the rock). Besides, the use of studded tire of cars and deicer agents influence the wear resistance in the winter period ${ }^{4}$.

Considering influence of an atmospheric precipitation on increase in wear of the top layer of asphalt concrete, investigated the size of wear of the dry and saturated with water asphalt concrete samples.

For this investigation on the test platform they drilled out the control asphalt cores samples

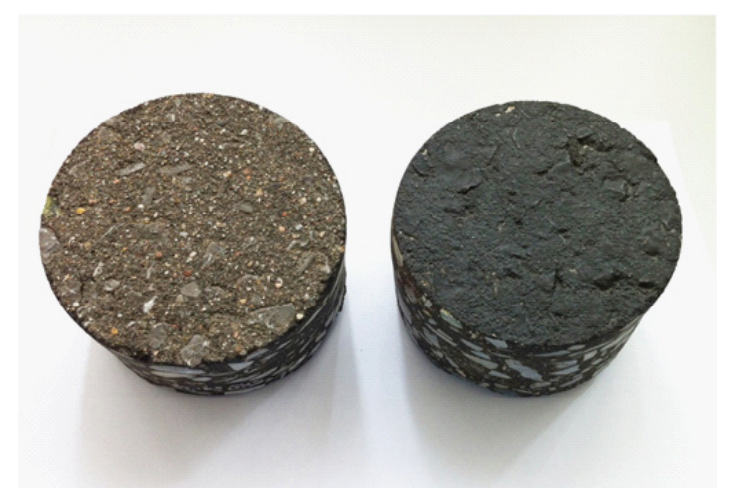

Fig. 1: Asphalt cores: the raw and processed impregnating composition (without impregnating composition) and the asphalt cores samples with impregnating composition. According to GOST 31015 water saturation of cuttings and core samples of the finished roadway should be not more than 3,5\% by volume (for the II and III climatic zone of Russia).

The samples testing were leaded on the wheel wear «LKI-2» in dry and water saturated state. The samples were saturated with a solution of deicer agents - sodium chloride, at a temperature of $20^{\circ} \mathrm{C}$.

Before the test, the samples were placed in an apparatus cage, ensuring equal load feed on them at the rate of $440 \mathrm{~kg} / \mathrm{cm}^{2}$; while they simultaneously used the moistened quartz sand for abrasion the samples. For a basic cycle of test 560 turns of a disk are taken that the corresponding about 204 passes of a wheel of the settlement car at the wheel stand are considered.

The wear (abrasion) of the samples cannot be more than $0.2 \mathrm{~g} / \mathrm{cm}^{2}$, according to the requirements ${ }^{5}$ for the roads with the traffic of more than 2000 cars/day.

The average annual wear of the roadway can't exceed more than $1,5 \mathrm{~mm}$ (or having a layer as thick as $4 \mathrm{~mm}$ - not more than 3,5\%) according to the layer thickness by the requirements ${ }^{4}$ for the lime-rock particles and the actual traffic volume at 7000 cars/day.

Wear (abrasion) W consists of the loss of the original mass $(\mathrm{g})$ per $1 \mathrm{sm}^{2}$ of the sample area

Table 1: Test results of samples of asphalt concrete pavement to the abrasion (wear properties)

\begin{tabular}{|c|c|c|c|c|}
\hline \multirow[t]{2}{*}{ Sample } & \multicolumn{2}{|c|}{ Dry samples after 560 cycles } & \multicolumn{2}{|c|}{ Samples rich in saline after 560 cycles } \\
\hline & $\begin{array}{l}\text { Wear, } \\
\text { g/sm² }\end{array}$ & $\begin{array}{c}\text { Abrasion } \\
\text { thickness, \% }\end{array}$ & $\begin{array}{l}\text { Wear, } \\
\text { g/sm² }\end{array}$ & $\begin{array}{c}\text { Abrasion } \\
\text { thickness, \% }\end{array}$ \\
\hline Without impregnation & 0,21 & 3,7 & 0,27 & 4,2 \\
\hline With impregnation & 0,19 & 3,3 & 0,2 & 3,5 \\
\hline $\begin{array}{l}\text { Requirements of } \\
\text { regulatory documents }\end{array}$ & $\begin{array}{l}\text { not more } \\
\text { than } 0,2\end{array}$ & $\begin{array}{c}\text { not more than } 3 \text {, } \\
5(\text { not more } \\
\text { than } 1,5 \mathrm{~mm})\end{array}$ & $\begin{array}{l}\text { not more } \\
\text { than } 0,2\end{array}$ & $\begin{array}{c}\text { not more than } 3 \text {, } \\
5(\text { not more } \\
\text { than } 1,5 \mathrm{~mm})\end{array}$ \\
\hline
\end{tabular}


and it is determinated with an accuracy of 0.01 $\mathrm{g} / \mathrm{cm}^{2}$ by the formula (1):

$$
W=\left(P-P_{1}\right): S
$$

where:

$\mathrm{P}$ - the mass of the dry sample to abrasion, $\mathrm{g}$;

$\mathrm{P}_{1}$ - the mass of the dry sample after the abrasion, g;

$\mathrm{S}$ - abrasion area of the sample, is equal to 64 $\mathrm{cm}^{2}$.

For the value of wear (abrasion) they take simple average of the five samples test results. Besides, the value of reducing the thickness sample was determined (in \%) as a result of abrasion (Table 1).

It is known that the strongest destructive effect on the roadway in use is the freezing of the water saturated asphalt concrete. When the water freezes and turns to ice, it increases in volume by $8-11 \%$. At the same time, there is an increase of the pore volume and a violation of asphalt concrete structure. Due to decrease of the water volume in the transition to the liquid state there is an additional saturation the pores by water and at the time of the next freezing there is a usual increase in their volume. Effect of water and frost of subjects is stronger, than more happens cycles of freezing and thawing ${ }^{6}$.

It was investigated the operating parameters of the samples of asphalt roadway (cores) on the test platform before and after processing by impregnating composition, and after the summer and winter operation of the test platform (Table 2).

Winter operation of the test platform happened in the conditions of winter in a zone of a temperate climate in the center of the East European Plain.

The maximal temperature ratio of the winter operation in the winter $2015-2016$, was $22.5^{\circ} \mathrm{C}$ (from 24.01.16 $\left(-18,6^{\circ} \mathrm{C}\right)$ until 31.01.16 $\left(+3,9^{\circ} \mathrm{C}\right)$ ). Atmospheric precipitation rate was exceeded to $19 \%$ (in December 2015) to $48 \%$ (in January 2016) and to $59 \%$ (February 2016). Summer operation of the test platform in February (summer 2016) - the temperature reached $32.3^{\circ} \mathrm{C}$ in June (26.06.16), 
$31.2^{\circ} \mathrm{C}$ in July $(15.07 .16)$, in August of $33.6^{\circ} \mathrm{C}$ (08.07.16). Atmospheric precipitation rate in the summer operation exceeded to $44 \%$ in July and to $104 \%$ in August ${ }^{7}$.

It is concluded that the operating parameters of the asphalt concrete road samples after processing by impregnating composition substantially did not change during the operation period under the high temperature drops in the winter operating conditions and during exposure of high temperature and solar radiation conditions in the summer operation. Atmospheric precipitation also did not influence on the asphalt concrete pavement samples operational parameters after processing by impregnating composition.

It was calculated the decrease of the car exhaust emissions as a result of reducing the amount of damage on the road treated by the impregnating composition, leading to the release of the largest amount of pollutants by the car due to braking and (or) stop the car before the road damage (holes, potholes, ruts) and its subsequent movement in the "acceleration" mode.

Table 3 shows estimates of the amounts of harmful components emission of exhaust gases, at which decreases the total amount of exhaust gas emissions due to reduced number of damages on the road with the impregnating composition. The data is given according to the road category, where the category A - car utilization 3000 cars/day, B - from 1,000 to 3,000 cars/day, B - less than 1000 cars/ day (according to GOST 50597-93) (Table 3).

Analysis of the calculated data in the Table 3 shows that when processing the impregnating composition on road asphalt concrete due to decrease of surface damage, the emissions of harmful exhaust gas components will decrease at each section of road category A - to 1569.456648 $\mathrm{kg} /$ day ( $1.5 \mathrm{~m} /$ day), category $B-$ to 1046.304432 $\mathrm{kg} /$ day $(\sim 1 \mathrm{t} / \mathrm{d})$ category $\mathrm{C}$ - to $523.152216 \mathrm{~kg} /$ day $(\sim 0.5 \mathrm{t} / \mathrm{d})$. This is in agreement with the conclusions in this paper ${ }^{5}$.

The impregnating composition is made on the basis of oil, so when they process it to the asphalt concrete, it fills all the voids of asphalt concrete, binds chemically with the organic component of asphalt concrete - bitumen. At the same time the film formed on the asphalt concrete surface protects the bitumen in this one from the solar radiation and high temperature ratios causing the thermo-oxidative aging of bitumen.

When the bitumen ages in the asphalt concrete, the volatile carcinogens from the asphalt steam and enter to the environment ${ }^{8,9}$. They carried out the calculations for the group of polycyclic aromatic hydrocarbons (PAHs) and these calculations

Table 3: The amount of harmful substances in exhaust gases of cars due to braking and (or) stop the car before the road damage

(holes, potholes, ruts) and its subsequent movement in the "acceleration" mode for various categories of roads

\begin{tabular}{|c|c|c|c|}
\hline \multirow{2}{*}{$\begin{array}{l}\text { Harmful } \\
\text { exhaust } \\
\text { components }\end{array}$} & \multicolumn{3}{|c|}{$\begin{array}{l}\text { The amount of matter emissions from } \\
\text { the exhaust gases of cars, } \mathrm{kg} / \text { day }\end{array}$} \\
\hline & A & B & C \\
\hline $\mathrm{CO}$ & 1296 & 864 & 432 \\
\hline $\mathrm{NO}_{2}$ & 43,2 & 28,8 & 14,4 \\
\hline $\mathrm{CH}_{4}^{2}$ & 172,8 & 115,2 & 57,6 \\
\hline Carbon black & 43,2 & 28,8 & 14,4 \\
\hline $\mathrm{SO}_{2}$ & 12,96 & 8,64 & 4,32 \\
\hline Formaldehyde & 1,296 & 0,864 & 0,432 \\
\hline Benzopyrene & 0,000648 & 0,000432 & 0,000216 \\
\hline Total & 1569,456648 & 1046,304432 & 523,152216 \\
\hline
\end{tabular}


have shown that the operational wear of the roadway cannot be an important primary source of air pollution by $\mathrm{PAH}$, because their maximum concentration at the boundary of the carriageway shall not exceed more than $0.01 \mathrm{MPCmr}$ (tentatively the safe level). Due to the fact that PAHs is capable of accumulation in the soil and water, this type of pollution cannot be excluded from the further study of the roadway use influence on the area pollution ${ }^{10}$.

The authors of the work noted ${ }^{4}$ that the protective impregnating compositions based on the bitumen, penetrates into the cracks and pores of the asphalt concrete and can reduce consumption of the deicing agent that adversely affect to the environment, because there is no icing of the impregnating compositions from the integral waterproofing by impregnating composition of the surface of the road asphalt concrete.

Thus, the protection of the surface of the asphalt concrete road by the impregnating composition retains the operational properties of bitumen for a longer period than to unprotected road surface, thereby affecting at the increase of maintenance-free service life while reducing the influence of the road construction works and materials on the environment, and on the resource conservation.

\section{CONCLUSION}

There were considered the environmental aspects of the use of impregnating compositions for protection of asphalt concrete road from the negative factors of natural and technogenic nature. It is found that application of impregnating composition allows to reduce wear of road asphalt concrete at loss of an atmospheric precipitation, and temperature differences. It is noted that the use of the impregnating composition for protection of the asphalt concrete road will be possible to promote reduction of the harmful exhaust gas components to the atmosphere due to reduction of damage the surface of the roadway. It is also contemplated that the use of impregnating compositions will reduce the amount of volatile carcinogens evaporated from the asphalt concrete road under the influence of high temperatures and solar radiation, and extends the life of maintenance-free operation of the roadway while reducing the influence of road construction works and materials on the environment.

\section{ACKNOWLEDGEMENT}

Applied researches are conducted with financial support of the state represented by the Ministry of Education and Science of Russia in under the Subsidy Grant Agreement No 14.579.21.0025 of June 5, 2014. (Unique Identifier for Applied Scientific Researches (project) RFMEFI57914X0025).

\section{REFERENCES}

1. Leonovich I.I., Melnikova I.S. Analiz prichin vozniknoveniya treshin v dorojnikh pokritiyakh i kriterii ikh treshinostoikosti. Stroitelnaya nauka i technika. 2011; 4: 37-41.

2. Chigorina E.A., Razinov A.L., Retivov V.M. Biosci. Biotech. Res. Asia. 2014; 11 (3): 167983.

3. Ubas'kina Y. A, Chigorina E. A, Razinov A. L, Ryabenko V. S, Kovtun I. D. Orient J Chem. 2016; 32 (1): 305-11.

4. Report on the application of impregnation «Dorsan». Arkangelskavtodor. Arkhangelsk: 2013; 1-8.

5. Gorelisheva L.A., Garmanov V.N., Petrov Yu.N.
Sbornik "Dorogi i mosti". 2015; 34: 115-27.

6. Filatov S. F., Richakova O.A.: Remont dorojnikh pokritii v zimnikh ysloviyakh granulirovannimi asfaltobetonnimi smesyami. Omsk: 2011;. 78.

7. Kazakov K. Weather and climate. Moscow. 2016.

8. Boffetta P., Jourenkova N., Gustavsson P. Cancer Causes \& Control. 1997; 8(3): 44472.

9. Hansen E.S. Scand J Work Environ Health. 1989; 15 (2): 101-5.

10. Levanchuk A.V. Hygiene and Sanitation. 2014; 6 (93): 17-21. 